The ability to vary the spring tension using a screw and the spatial geometry of the three pegs makes the device suitable for a wide variety of specimen shapes and sizes.

Interference by diffraction from the $\mathrm{Al}$ holder appears only as a small peak on the high-angle side of the diffractograph.

An example where retention of the corroded scale in situ is necessary for continuance of testing, and to minimize interference owing to extraction of substrate phases is given in the analysis of oxidation of austenitic steels at high temperature.

The diffractographs are shown in Fig. 2.

The approximately $8 \mu \mathrm{m}$ thick corrosion layer resulting from a $100 \mathrm{~h}$ treatment of an austenitic steel (HK 45) in an oxidizing environment at $1090 \mathrm{~K}$ consists of $\mathrm{Cr}_{2} \mathrm{O}_{3}$ and an iron chromium spinel.

The diffractographs show that the in situ measurement of the oxide scale reveals the presence of some matrix. The disturbing presence of $M_{23} \mathrm{C}_{6}$ which is obvious in the extracted scale is absent in the in situ measurement. The diffractograph $(c)$ of the substrate after oxide-scale removal is also recorded using the specimen holder described.

\section{PAUL TAMBUYSER}

Joint Research Center

Petten Establishment

Postbus 2

1755 ZG Petten

The Netherlands

(Received 26 August 1985; accepted 4 February 1986)

\section{Crystallographers}

\section{J. Appl. Cryst. (1986). 19, 204}

This section is intended to be a series of short paragraphs dealing with the activities of crystallographers. such as their changes of position. promotions, as sumption of significant new duties, honours, etc. Items for inclusion, subject to the approval of the Editorial Board. should be sent to the Executive Secretary of the International Union of Crystallography (J. N. King. International Union of Crystallography, 5 Abbey Square, Chester $\mathrm{CH} 12 \mathrm{HU}$. England).

Professor Charles E. Bugg, Department of Chemistry at the University of Alabama, Birmingham, has been elected VicePresident of the American Crystallographic Association for 1986 and will become President in 1987. Dr William L. Duax, Medical Foundation of Buffalo, is the current President. Professor Hugo Steinfink, Department of Materials Science and Engineering at the University of Texas, continues as Secretary. Catharine Foris, E. I. du Pont de Nemours \& Co., will succeed Dr Robert A. Sparks, Nicolet Corporation, as Treasurer on 1 July 1986.

Professor Bugg and Professor Steinfink are Co-editors of Acta Crystallographica and Dr Duax is Secretary of the Union's Commission on Small Molecules.

\section{International Union of Crystallography}

\section{J. Appl. Cryst. (1986). 19, 204}

International Union of Crystallography announces the Ewald Prize

The International Union of Crystallography announces the establishment of the Ewald Prize for outstanding contributions to the science of crystallography. The name of the prize has been chosen with the kind consent of the late Paul Peter Ewald, to recognize Professor Ewald's significant contributions to the foundations of crystallography and to the founding of the International Union of Crystallography, especially his services as the President of the Provisional International Crystallographic Committee from 1946 to 1948 , as the first Editor of the Union's publication Acta Crystallographica from 1948 to 1959 , and as the President of the Union from 1960 to 1963.

The prize consists of a medal, a certificate and a financial award. It will be presented once every three years during the triennial International Congresses of Crystallography. The first prize will be presented during the XIV Congress at Perth, Australia, in 1987. This year will be the seventy-fifth anniversary of the discovery of X-ray diffraction in 1912.

Any scientist who has made contributions of exceptional distinction to the science of crystallography is eligible for the Ewald Prize, irrespective of nationality, age or experience. No restrictions are placed on the time or the means of publication of his or her contributions. The prize may be shared by several contributors to the same scientific achievement.

Nominations for the Ewald Prize are invited. They should be submitted in writing, accompanied by supporting docu- mentation, to the Executive Secretary of the International Union of Crystallography, 5 Abbey Square, Chester $\mathrm{CH} 1$ $2 \mathrm{HU}$, United Kingdom. The closing date for nominations is 30 September 1986

TH. HaHN

President

K. V. J. KURKI-SUONIO General Secretary

\section{Notes and News}

\section{J. Appl. Cryst. (1986). 19, 204}

\section{AACG Crystal Growth Awards}

\section{Call for nominations}

The American Association of Crystal Growth sponsors two triennial awards that will be presented next at the National Meeting, ACCG-7, to be held in Monterey, California, 12-17 July 1987 . The awards may be shared by more than one person, and the recipient(s) of these awards will be invited, at that time, to deliver a lecture on the subject for which they are cited.

AACG International Crystal Growth Award

This award is presented for outstanding contributions to the field of crystal growth through technical achievements, publications, and presentations, and through their impact, worldwide, on science and technology. The award consists of a framed citation, a commemorative medal, and an honorarium of $\$ 3000$. Nominees may hold any nationality. Previous recipients of this award were Sir Charles Frank (University of Bristol, England), Dr Robert A. Laudise (AT\&T Bell Laboratories, USA) and Professor Bruce Chalmers (Harvard University, USA).

\section{AACG Young Author Award}

This award is presented for significant contributions to the field of crystal growth through publications in accredited journals, with emphasis on contributions following formal training. The nominee shall not be more than 35 years old at the deadline for nominations. The award consists of a framed citation and an honorarium of $\$ 1000$. Nominees may hold any nationality, but only research performed in the United States can be cited.

Nominations for these awards, together with supporting documentation, should be sent before 1 October 1986 to the AACG Awards Committee Chairman: Dr R. Ghez, IBM Watson Research Center, Yorktown Heights, NY 10598, USA. 